\title{
Effect of Growth Stage on the Efficacy of Postemergence Herbicides on Four Weed Species of Direct-Seeded Rice
}

\author{
Bhagirath Singh Chauhan and Seth Bernard Abugho \\ Crop and Environmental Sciences Division, International Rice Research Institute, Los Baños, Philippines \\ Correspondence should be addressed to Bhagirath Singh Chauhan, b.chauhan@irri.org
}

Received 26 October 2011; Accepted 21 December 2011

Academic Editor: David W. Archer

Copyright ( $) 2012$ B. S. Chauhan and S. B. Abugho. This is an open access article distributed under the Creative Commons Attribution License, which permits unrestricted use, distribution, and reproduction in any medium, provided the original work is properly cited.

\begin{abstract}
The efficacy of bispyribac-sodium, fenoxaprop + ethoxysulfuron, and penoxsulam + cyhalofop was evaluated against barnyardgrass, Chinese sprangletop, junglerice, and southern crabgrass when applied at four-, six-, and eight-leaf stages. When applied at the four-leaf stage, bispyribac-sodium provided greater than $97 \%$ control of barnyardgrass, junglerice, and southern crabgrass; however, it was slightly weak ( $74 \%$ control) on Chinese sprangletop. Irrespective of the weed species, fenoxaprop + ethoxysulfuron provided greater than $97 \%$ control when applied at the four-leaf stage. At the same leaf stage, penoxsulam + cyhalofop controlled 89 to $100 \%$ barnyardgrass, Chinese sprangletop, and junglerice and only $54 \%$ of southern crabgrass. The efficacy of herbicides was reduced when applied at the eight-leaf stage of the weeds; however, at this stage, fenoxaprop + ethoxysulfuron was effective in controlling $99 \%$ of Chinese sprangletop. The results demonstrate the importance of early herbicide application in controlling the weeds. The study identified that at the six-leaf stage of the weeds, fenoxaprop + ethoxysulfuron can effectively control Chinese sprangletop and southern crabgrass, penoxsulam + cyhalofop can effectively control Chinese sprangletop, and bispyribac-sodium can effectively control junglerice.
\end{abstract}

\section{Introduction}

Rice is an important crop in Asia, where 90\% of this crop is grown and consumed. Rice is traditionally grown by transplanting seedlings into puddled soil. Recently, due to high labor cost and less availability of water, there has been a trend to shift from transplanting to direct-seeded rice (DSR) in many Asian countries [1]. However, weeds are a greater problem in DSR than in transplanted rice because of the absence of the crop seedling size advantage and standing water at the time of crop emergence [2].

Many weeds, including barnyardgrass (Echinochloa crusgalli (L.) Beauv.), Chinese sprangletop (Leptochloa chinensis L.), junglerice (Echinochloa colona (L.) Link), and southern crabgrass (Digitaria ciliaris (Retz.) Koel.) are problematic grass species in DSR $[3,4]$. Barnyardgrass and junglerice are examples of "crop mimicry" as they closely resemble rice at the seedling stage. By the time these weeds can be easily recognized by farmers, crop yield losses may already be inevitable [5]. In DSR, junglerice and southern crabgrass seedling emergence was greater in a no-till system compared with a conventionally tilled system [6]. In another study, rice residue of up to $4 \mathrm{Mg} \mathrm{ha}^{-1}$ was not able to reduce the growth of barnyardgrass [7], suggesting that the crop residue at this amount, as a mulch on the soil surface, may not provide suppression of this weed. Barnyardgrass at a density of 9 plants $\mathrm{m}^{-2}$ can reduce rice yield by more than $50 \%$ [8] and heavy infestation of this weed can remove up to $80 \%$ of the nitrogen $(\mathrm{N})$ from the soil [9]. In a recent study, Chinese sprangletop grown under rice interference responded with increased leaf area ratio (amount of leaf area per unit plant dry biomass) and specific leaf area (amount of leaf area per unit leaf biomass), reflecting changes in the distribution of leaf biomass under competition [10]. Furthermore, Chinese sprangletop was not a prevalent and dominant weed in rice fields of Malaysia while transplanting of rice was the usual establishment method, but it became widespread with the shift to DSR [11]. These studies suggest the importance of these weed species in DSR. 

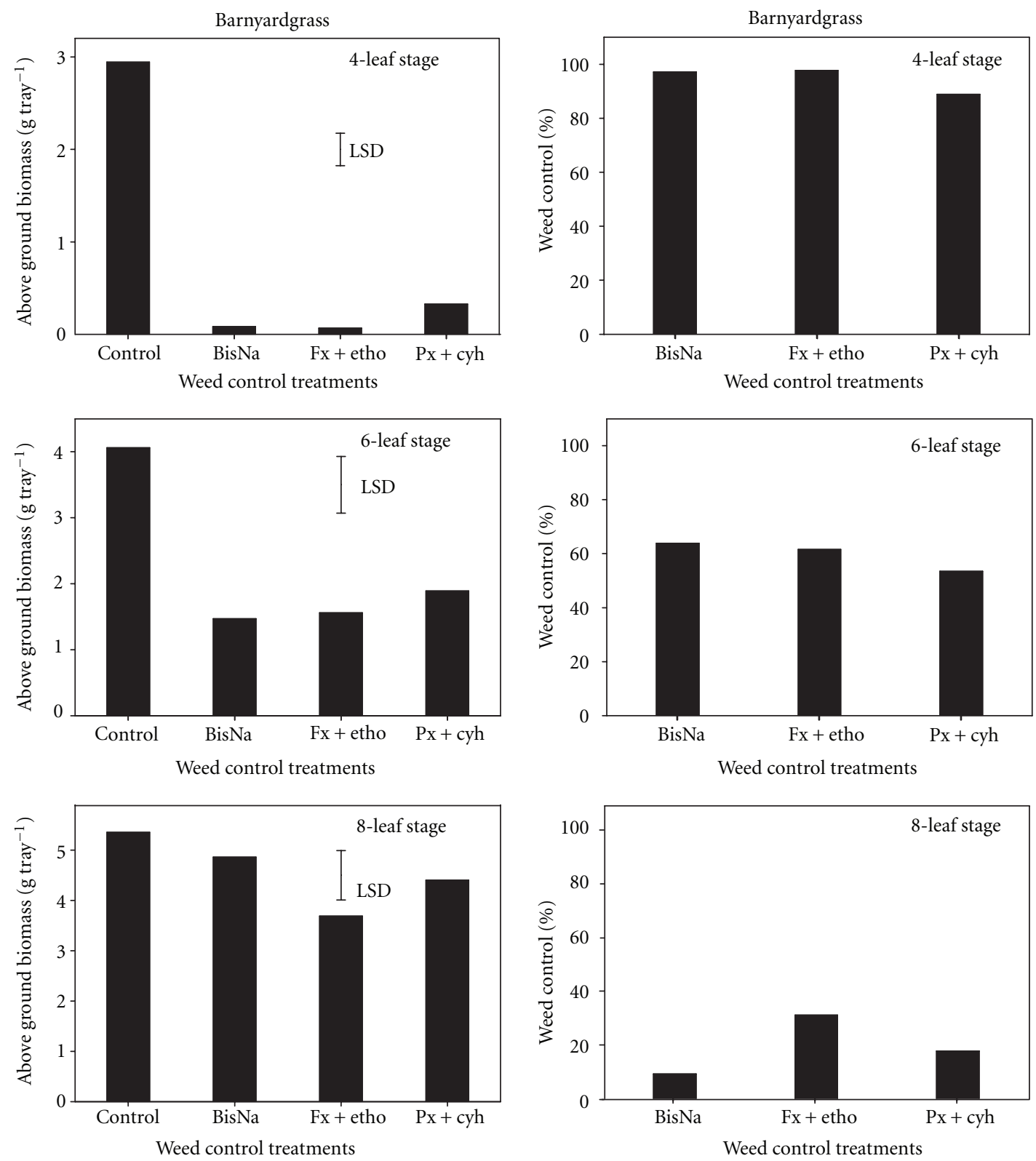

Figure 1: Effect of postemergence herbicides (BisNa, bispyribac-sodium; Fx + etho, fenoxaprop-p-ethyl + ethoxysulfuron; Px + cyh, penoxsulam + cyhalofop) on aboveground dry biomass (g) and control (\%) of barnyardgrass when sprayed at its four-, six-, and eightleaf stages. Mean comparisons were performed based on least significant difference test at $5 \%$.

Postemergence herbicides are a major tool used to control weeds in DSR. The growth stage of weed species may have an effect on herbicide efficacy by influencing uptake and metabolism of herbicides [12]. Diclofop, for example, was more effective on green foxtail (Setaria viridis (L.) Beauv.) and wild oat (Avena fatua L.) when applied at an early growth stage [13]. Conversely, trifloxysulfuron was more effective on yellow nutsedge (Cyperus esculentus L.) at late application stages [12]. Generally, the herbicide efficacy is lower when applied on bigger weeds. The herbicide degradation rate may be faster in big plants, and herbicide rates may need to be increased to achieve the same level of control [12]. In addition, reliance on a single herbicide may result in evolution of herbicide resistance in weeds and shift in weed flora. In Sri Lanka, for example, continuous use of bispyribac-sodium to control propanil-resistant barnyardgrass has resulted in a shift to dominance by Chinese sprangletop in rice [14]. There are reports from India that Chinese sprangletop is poorly controlled by bispyribac-sodium [15]. Therefore, optimum time of herbicide application and range of herbicides may help control these weeds effectively.

The objective of this study was to evaluate the efficacy of different postemergence herbicides on barnyardgrass, Chinese sprangletop, junglerice, and southern crabgrass when applied at their different growth stages. 

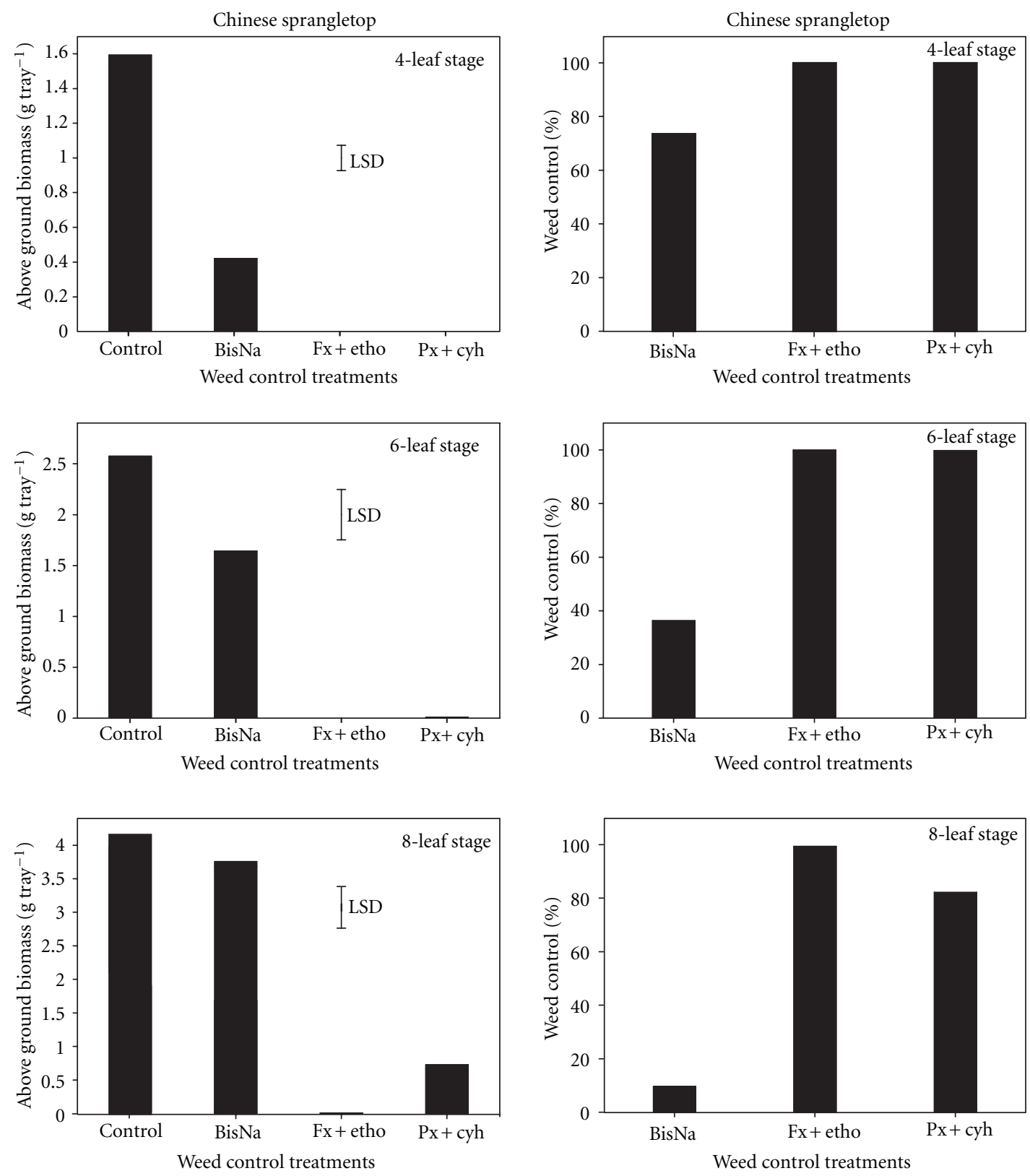

FIGURE 2: Effect of postemergence herbicides (BisNa, bispyribac-sodium; Fx + etho, fenoxaprop-p-ethyl + ethoxysulfuron; Px + cyh, penoxsulam + cyhalofop) on aboveground dry biomass (g) and control (\%) of Chinese sprangletop when sprayed at its four-, six-, and eight-leaf stages. Mean comparisons were performed based on least significant difference test at $5 \%$.

\section{Materials and Methods}

2.1. Experimental Details. Greenhouse experiments were conducted at the International Rice Research Institute, Los Baños, Philippines. Twenty-five seeds, each of barnyardgrass, Chinese sprangletop, junglerice, and southern crabgrass were planted on the soil surface in plastic trays $(8 \mathrm{~cm}$ by $8 \mathrm{~cm}$ by $5 \mathrm{~cm}$ ). Soil used in this study was collected from upland rice fields and it had a $\mathrm{pH}$ of 6.6 with $31 \%$ sand, $37 \%$ silt, and $32 \%$ clay. Seedlings were thinned to 10 plants per tray immediately after emergence. No fertilizer was applied to the weeds.
Plants were sprayed at the four-, six-, and eight-leaf stages using a research track sprayer that delivered $210 \mathrm{~L} \mathrm{ha}^{-1}$ spray solution at a spray pressure of $140 \mathrm{kPa}$. Flat nozzles (Teejet 80015) were used in the sprayer. The postemergence herbicide treatments included bispyribac-sodium at $30 \mathrm{gaiha}^{-1}$ and commercial mixtures of fenoxaprop-pethyl + ethoxysulfuron at $45 \mathrm{~g}$ ai ha $^{-1}$, and penoxsulam + cyhalofop at $72 \mathrm{~g}$ ai ha $^{-1}$. There were control treatments for each leaf stage and weed species in which herbicides were not sprayed.

Plants were watered daily such that there was no water stress in the plants. Seedling survival was determined $14 \mathrm{~d}$ 
TABLE 1: Effect of postemergence herbicides on seedling survival (\%) of barnyardgrass, Chinese sprangletop, junglerice, and southern crabgrass when sprayed at their four-, six-, and eight-leaf stage.

\begin{tabular}{|c|c|c|c|c|}
\hline \multirow{3}{*}{ Weed control treatment } & \multirow{3}{*}{$\begin{array}{l}\text { Rate } \\
\mathrm{gha}^{-1}\end{array}$} & \multicolumn{3}{|c|}{ Seedling survival } \\
\hline & & Four-leaf & Six-leaf & Eight-leaf \\
\hline & & & $\%$ & \\
\hline \multicolumn{5}{|l|}{ Barnyardgrass } \\
\hline Untreated control & 0 & 100 & 100 & 100 \\
\hline Bispyribac-sodium & 30 & 19 & 94 & 100 \\
\hline Fenoxaprop-p-ethyl + ethoxysulfuron & 45 & 13 & 56 & 80 \\
\hline Penoxsulam + cyhalofop & 72 & 63 & 83 & 100 \\
\hline $\mathrm{LSD}_{0.05}$ & & 17 & 22 & 12 \\
\hline \multicolumn{5}{|l|}{ Chinese sprangletop } \\
\hline Untreated control & 0 & 100 & 100 & 100 \\
\hline Bispyribac-sodium & 30 & 91 & 99 & 100 \\
\hline Fenoxaprop-p-ethyl + ethoxysulfuron & 45 & 0 & 1 & 1 \\
\hline Penoxsulam + cyhalofop & 72 & 0 & 2 & 61 \\
\hline $\mathrm{LSD}_{0.05}$ & & 13 & 3 & 17 \\
\hline \multicolumn{5}{|l|}{ Junglerice } \\
\hline Untreated control & 0 & 100 & 100 & 100 \\
\hline Bispyribac-sodium & 30 & 4 & 0 & 48 \\
\hline Fenoxaprop-p-ethyl + ethoxysulfuron & 45 & 6 & 41 & 89 \\
\hline Penoxsulam + cyhalofop & 72 & 16 & 53 & 89 \\
\hline $\mathrm{LSD}_{0.05}$ & & 11 & 20 & 18 \\
\hline \multicolumn{5}{|l|}{ Southern crabgrass } \\
\hline Untreated control & 0 & 100 & 100 & 100 \\
\hline Bispyribac-sodium & 30 & 9 & 82 & 100 \\
\hline Fenoxaprop-p-ethyl + ethoxysulfuron & 45 & 0 & 7 & 65 \\
\hline Penoxsulam + cyhalofop & 72 & 91 & 100 & 100 \\
\hline $\mathrm{LSD}_{0.05}$ & & 14 & 15 & 17 \\
\hline
\end{tabular}

after herbicide application with the criterion of at least one green leaf on the plant. Aboveground biomass was measured after drying plant samples in an oven at $70^{\circ} \mathrm{C}$ for $72 \mathrm{~h}$ and expressed as percent control.

2.2. Statistical Analyses. The experiments with each weed species were conducted twice using a randomized complete block design with five replicates. Because there was no significant interaction between treatments and experiments, the data from the repeated experiments were pooled $(n=10)$ before being subjected to ANOVA (GenStat 8.02005$)$. The data were analyzed separately for each leaf stage by using oneway ANOVA. Mean comparisons were performed based on least significant difference test at 0.05 probability.

\section{Results and Discussion}

3.1. Barnyardgrass. All herbicides had a phytotoxic effect on plant survival when applied at the early growth stage of barnyardgrass. Delayed herbicide application after the four-leaf stage increased the number of surviving plants, and all plants of barnyardgrass survived when bispyribacsodium and penoxsulam + cyhalofop were applied at its eight-leaf stage (Table 1). Irrespective of the growth stage of barnyardgrass, there was no difference in efficacy of these herbicides and the biomass and percent weed control decreased with the progress in weed growth (Figure 1). The application of all herbicides gave $89-98 \%$ weed control of barnyardgrass when applied at the four-leaf stage. However, delayed application from the four-leaf to the six-leaf stages reduced the control to 53-64\%. Similarly, in a previous study in India, fenoxaprop + ethoxysulfuron $\left(150+18 \mathrm{~g}_{\text {ai ha }}{ }^{-1}\right)$ sprayed $21 \mathrm{~d}$ after sowing in dry-seeded rice gave $68 \%$ control of barnyardgrass [16]. In our study, very poor weed control (9-31\%) of barnyardgrass (3.7-4.9 $\mathrm{g}_{\text {biomass tray }}$ bi $^{-1}$ in herbicide treatments versus $5.4 \mathrm{~g}^{\text {biomass }}$ tray $^{-1}$ in the untreated control) was achieved when these herbicides were applied at their eight-leaf stage.

3.2. Chinese Sprangletop. No (or very few) seedlings of Chinese sprangletop survived when fenoxaprop + ethoxysulfuron and penoxsulam + cyhalofop were applied at its fourand six-leaf stages (Table 1). However, when penoxsulam + cyhalofop were applied at the eight-leaf stage, more than $60 \%$ Chinese sprangletop seedlings survived (with at least one green leaf). Chinese sprangletop sprayed with bispyribacsodium had more surviving plants than those sprayed with the other two herbicides, and this was true at all leaf stages. Bispyribac-sodium at any stage of Chinese sprangletop was not able to kill more than $10 \%$ seedlings (Table 1 ). 

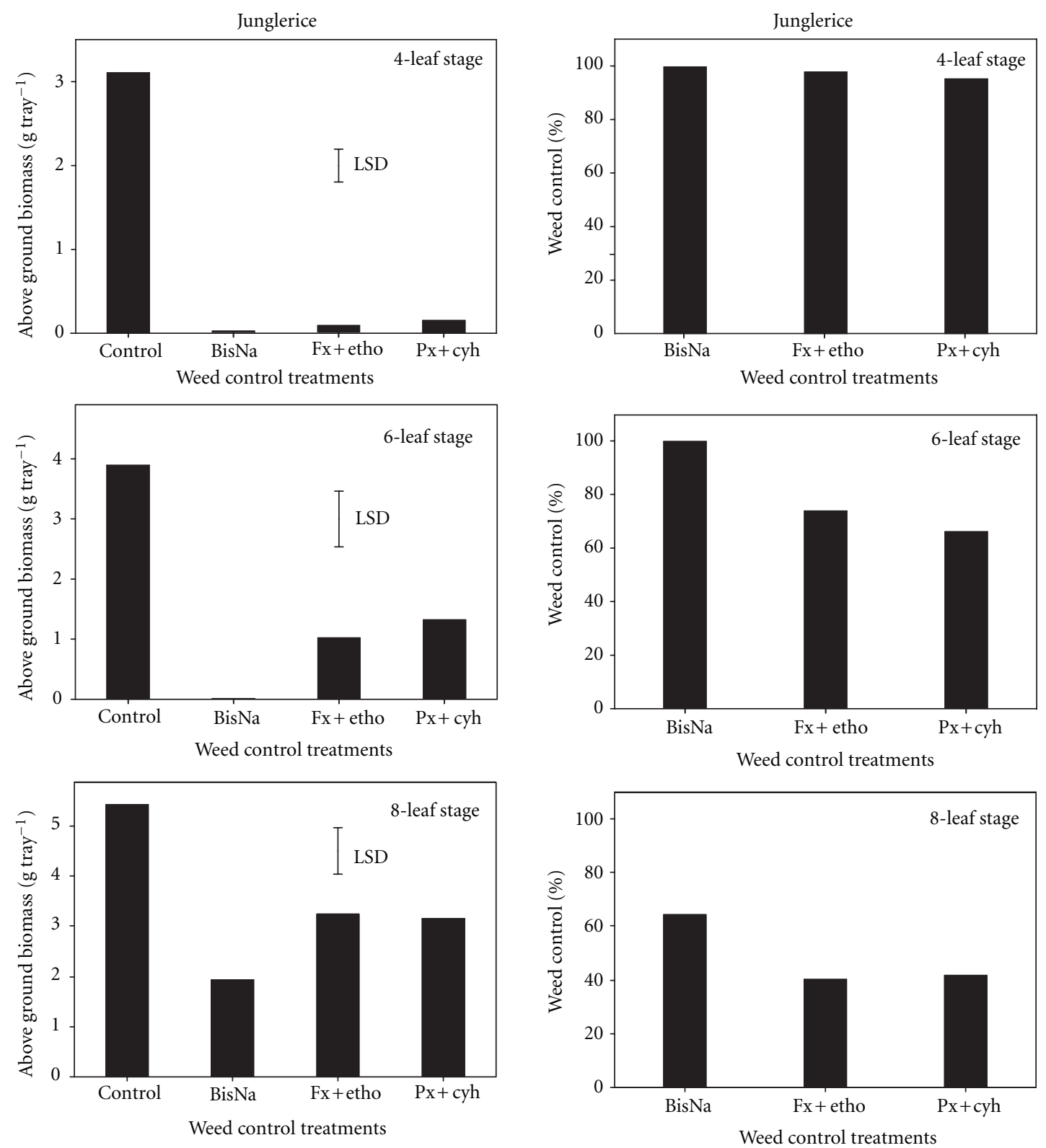

FIGURE 3: Effect of postemergence herbicides (BisNa, bispyribac-sodium; Fx + etho, fenoxaprop-p-ethyl + ethoxysulfuron; Px + cyh, penoxsulam + cyhalofop) on aboveground dry biomass (g) and control (\%) of junglerice when sprayed at its four-, six-, and eight-leaf stages. Mean comparisons were performed based on least significant difference test at $5 \%$.

Penoxsulam + cyhalofop gave more than $99 \%$ weed control when applied at the four-to-six-leaf stage (Figure 2). The control of Chinese sprangletop with this herbicide was slightly reduced ( $82 \%$ control) when application was delayed to the eight-leaf stage. Irrespective of leaf stage, fenoxaprop + ethoxysulfuron was very effective in controlling (>99\%) Chinese sprangletop (Figure 2). On the other hand, the effect of bispyribac-sodium on this weed was poor and control decreased with progress in weed growth $(74,36$, and $10 \%$ control at the four-, six-, and eight-leaf stages, resp.). This is consistent with reports from India where bispyribacsodium was shown to be weak on Chinese sprangletop [15]. Penoxsulam alone was also not effective in controlling
Chinese sprangletop [15]; however, its commercial mixture with cyhalofop was able to control this weed effectively.

3.3. Junglerice. As observed in barnyardgrass, all herbicides had a phytotoxic effect on junglerice survival when applied at the early stage; however, delayed herbicide application increased the number of surviving plants (Table 1). As compared with the untreated control, the herbicides used in our study reduced more than $95 \%$ junglerice biomass when applied at its four-leaf stage (Figure 3). Delayed application of fenoxaprop + ethoxysulfuron and penoxsulam + cyhalofop from the four-to-six-leaf stage reduced junglerice control to $66-74 \%$; however, bispyribac-sodium still gave greater 

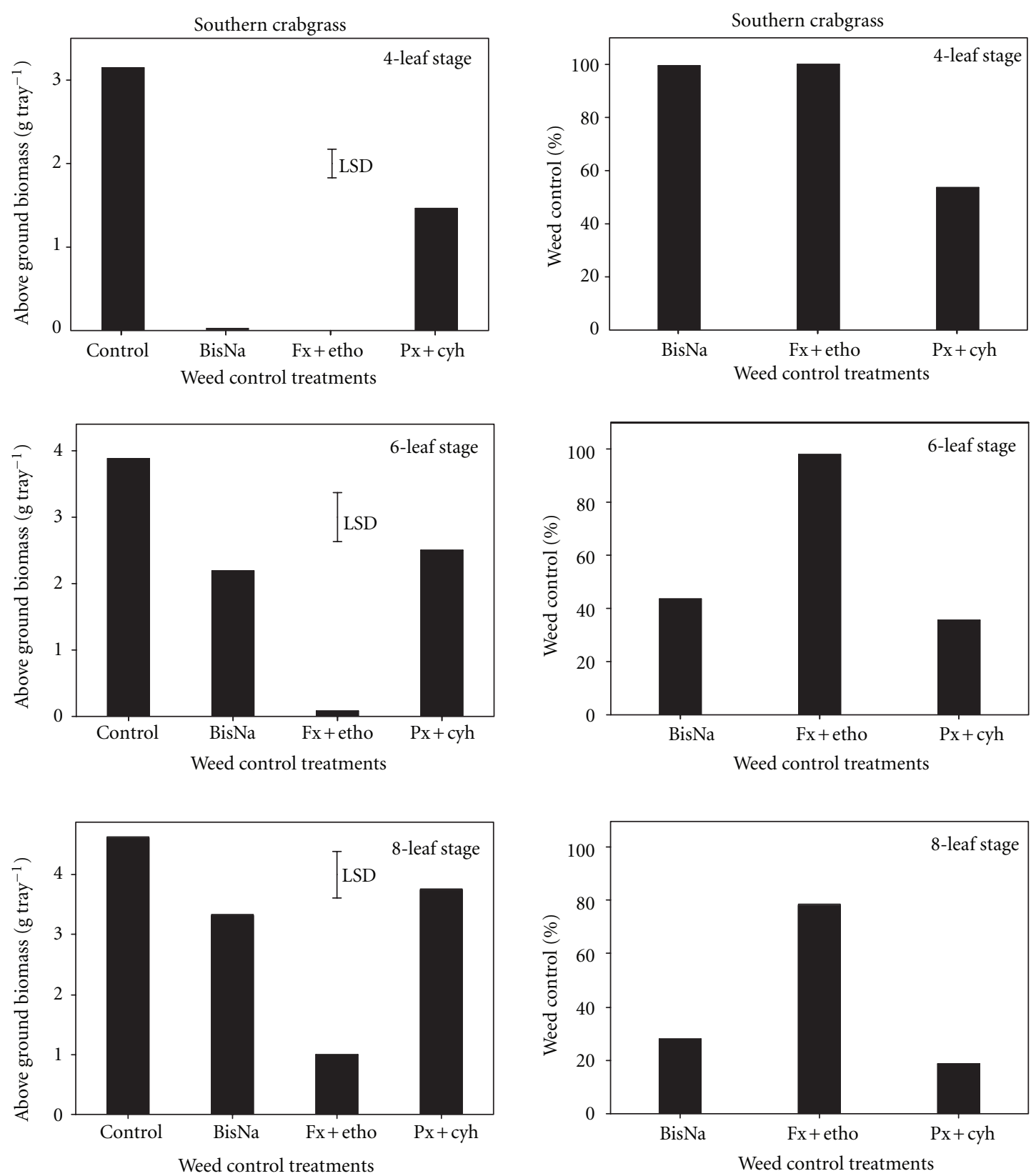

FIgURE 4: Effect of postemergence herbicides (BisNa, bispyribac-sodium; Fx+etho, fenoxaprop-p-ethyl + ethoxysulfuron; Px+cyh, penoxsulam + cyhalofop) on aboveground dry biomass (g) and control (\%) of southern crabgrass when sprayed at its four-, six-, and eight-leaf stages. Mean comparisons were performed based on least significant difference test at $5 \%$.

than $99 \%$ junglerice control at this stage. Recently, this herbicide has been widely used by farmers in India and Sri Lanka to control junglerice. Weed control by all herbicides was reduced to $40-64 \%$ when applied at the eight-leaf stage. Earlier, fenoxaprop + ethoxysulfuron $\left(150+18 \mathrm{~g}\right.$ a ha $\left.^{-1}\right)$ sprayed $21 \mathrm{~d}$ after rice sowing gave $83 \%$ control of junglerice; however, the study did not mention the leaf stage of the weed [16].

3.4. Southern Crabgrass. Only a few plants $(<10 \%)$ of southern crabgrass survived when fenoxaprop + ethoxysulfuron were applied at the four- or six-leaf stages and greater than $90 \%$ plants survived when penoxsulam + cyhalofop were applied at these same stages (Table 1). Bispyribac and fenoxaprop + ethoxysulfuron gave more than $99 \%$ control of southern crabgrass when applied at the four-leaf stage (Figure 4). However, the efficacy of bispyribac was reduced markedly when application was delayed from four-to-six-leaf stage. Fenoxaprop + ethoxysulfuron was the most effective herbicide in controlling southern crabgrass at the six- (98\%) and eight-leaf stage (78\%). Penoxsulam + cyhalofop, on the other hand, did not effectively control southern crabgrass at any leaf stage: 54,36 , and $19 \%$ control at the four-, six-, and eight-leaf stage, respectively (Figure 4 ). This could be due to 
lower herbicide uptake translocation or to faster metabolism [12].

\section{Conclusions}

The results demonstrate the importance of early herbicide application in controlling the weeds. Generally, the effectiveness of herbicides was low on weeds when applied at their eight-leaf stage. The herbicide degradation rate or metabolism could be faster in big plants, thus herbicide rates may need to be increased to achieve the same level of control [12]. In situations such as rains, farmers may not be able to apply postemergence herbicides at the early stage. Our study identified that at the six-leaf stage of the weeds, fenoxaprop + ethoxysulfuron can effectively control Chinese sprangletop and southern crabgrass, penoxsulam + cyhalofop can effectively control Chinese sprangletop, and bispyribac-sodium can effectively control junglerice. It has been suggested that the control of barnyardgrass is improved with the addition of urea ammonium nitrate to bispyribac [17]. However, it is also possible that the interaction between herbicide and fertilizer may influence the amount of crop injury [3]. Fenoxaprop may cause injury on rice plants. Further research is therefore needed to understand the interaction of these postherbicides and nitrogen fertilizer on rice growth and yield.

\section{References}

[1] S. Pandey and L. Velasco, "Trends in crop establishment methods in Asia and research issues," in Rice Is Life: Scientific Perspectives for the 21st Century, Japan International Research Center for Agricultural Sciences, pp. 178-181, International Rice Research Institute and Tsukuba, Los Baños, Philippines, 2005.

[2] B. S. Chauhan and D. E. Johnson, "The role of seed ecology in improving weed management strategies in the tropics," Advances in Agronomy, vol. 105, pp. 221-262, 2009.

[3] B. S. Chauhan and D. E. Johnson, "Growth response of directseeded rice to oxadiazon and bispyribac-sodium in aerobic and saturated soils," Weed Science, vol. 59, no. 1, pp. 119-122, 2011.

[4] B. S. Chauhan, V. P. Singh, A. Kumar, and D. E. Johnson, "Relations of rice seeding rates to crop and weed growth in aerobic rice," Field Crops Research, vol. 121, no. 1, pp. 105-115, 2011.

[5] L. G. Holm, D. L. Plucknett, J. V. Pancho, and J. P. Herberger, The World's Worst Weeds: Distribution and Biology, The University Press of Hawaii, Malabar, Fla, USA, 1991.

[6] B. S. Chauhan and D. E. Johnson, "Influence of tillage systems on weed seedling emergence pattern in rainfed rice," Soil and Tillage Research, vol. 106, no. 1, pp. 15-21, 2009.

[7] B. S. Chauhan and D. E. Johnson, "Row spacing and weed control timing affect yield of aerobic rice," Field Crops Research, vol. 121, no. 2, pp. 226-231, 2011.

[8] M. A. Maun and S. C. H. Barrett, "The biology of Canadian weeds. 77. Echinochloa crus-galli (L.) Beauv," Canadian Journal of Plant Science, vol. 66, pp. 739-759, 1986.

[9] L. G. Holm, D. L. Plucknett, J. V. Pancho, and J. P. Herberger, The World's Worst Weeds: Distribution and Biology, University of Hawaii Press, Honolulu, Hawaii, USA, 1977.
[10] B. S. Chauhan and D. E. Johnson, "Ecological studies on Echinochloa crus-galli and the implications for weed management in direct-seeded rice," Crop Protection, vol. 30, no. 11, pp. 1385-1391, 2011.

[11] M. Azmi, D. V. Chin, P. Vongsaroj, and D. E. Johnson, "Emerging issues in weed management of direct-seeded rice in Malaysia, Vietnam, and Thailand," in Rice Is Life: Scientific Perspectives for the 21st Century, Japan International Research Center for Agricultural Sciences, pp. 196-198, International Rice Research Institute and Tsukuba, Los Baños, Philippines, 2005.

[12] S. Singh and M. Singh, "Effect of growth stage on trifloxysulfuron and glyphosate efficacy in twelve weed species of citrus groves," Weed Technology, vol. 18, no. 4, pp. 1031-1036, 2004.

[13] H. A. Friesen, P. A. O'Sullivana, and W. H. Vanden Born, "HOE 23408, a new selective herbicide for wild oats and green foxtail in wheat and barley," Canadian Journal of Plant Science, vol. 56, pp. 567-578, 1976.

[14] B. Marambe, "Emerging weed problems in wet-seeded rice due to herbicide use in Sri Lanka," in Proceedings of the International Rice Congress, p. 430, Beijing, China, 2002.

[15] R. Gopal, R. K. Jat, R. K. Malik et al., "Direct dry seeded rice production technology and weed management in ricebased systems," Tech. Rep., International Maize and Wheat Improvement Center, New Delhi, India, 2010.

[16] S. Singh, L. Bhushan, J. K. Ladha, R. K. Gupta, A. N. Rao, and B. Sivaprasad, "Weed management in dry-seeded rice (Oryza sativa) cultivated in the furrow-irrigated raised-bed planting system," Crop Protection, vol. 25, no. 5, pp. 487-495, 2006.

[17] C. H. Koger, D. M. Dodds, and D. B. Reynolds, "Effect of adjuvants and urea ammonium nitrate on bispyribac efficacy, absorption, and translocation in barnyardgrass (Echinochloa crus-galli). I. Efficacy, rainfastness, and soil moisture," Weed Science, vol. 55, no. 5, pp. 399-405, 2007. 


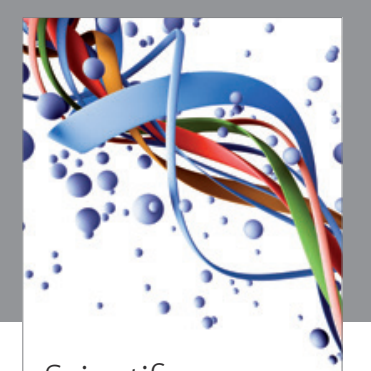

Scientifica
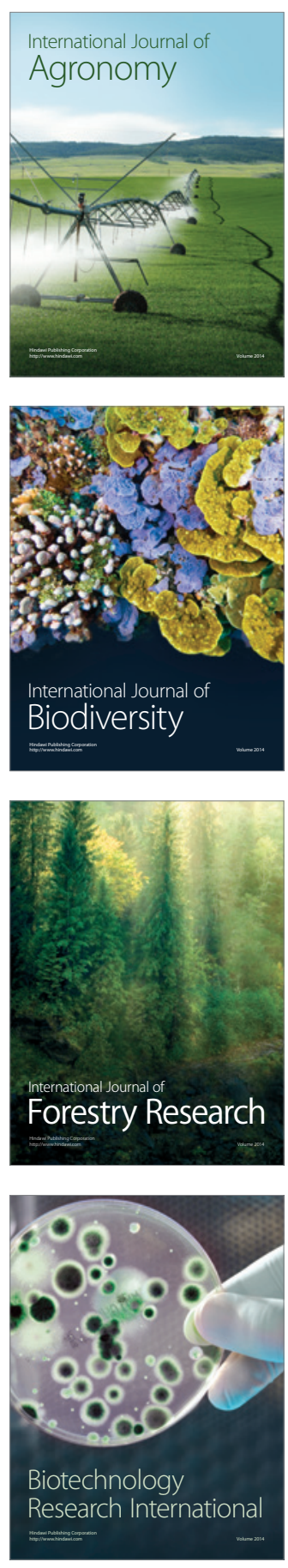
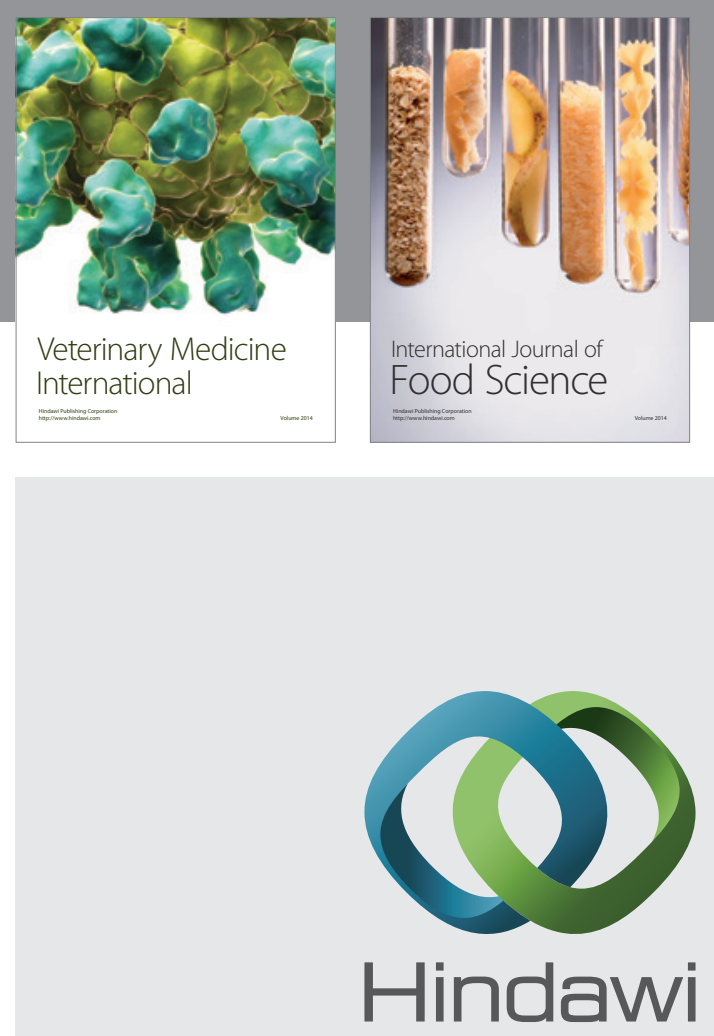

Submit your manuscripts at

http://www.hindawi.com
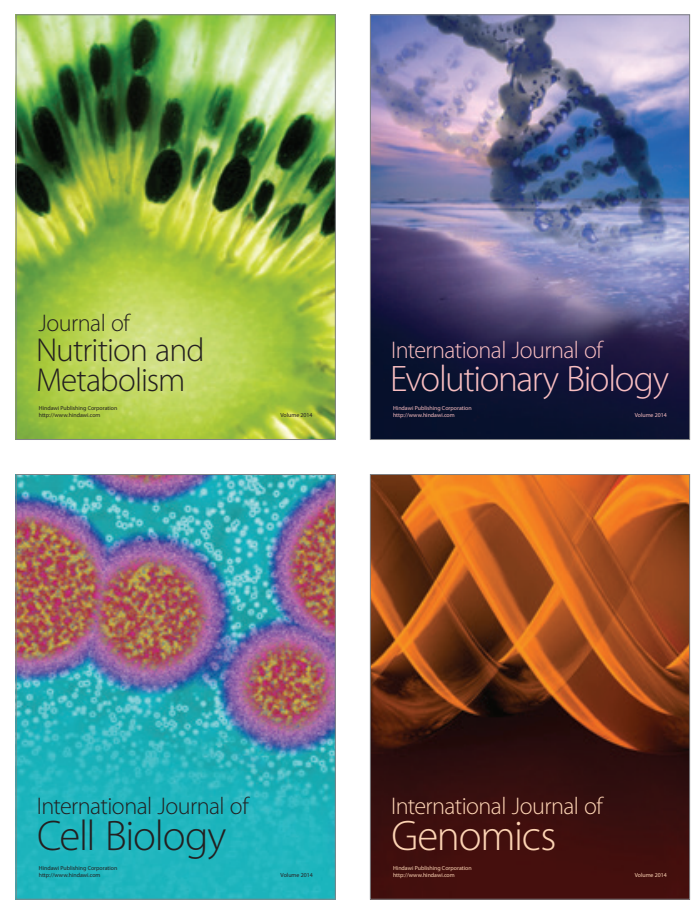
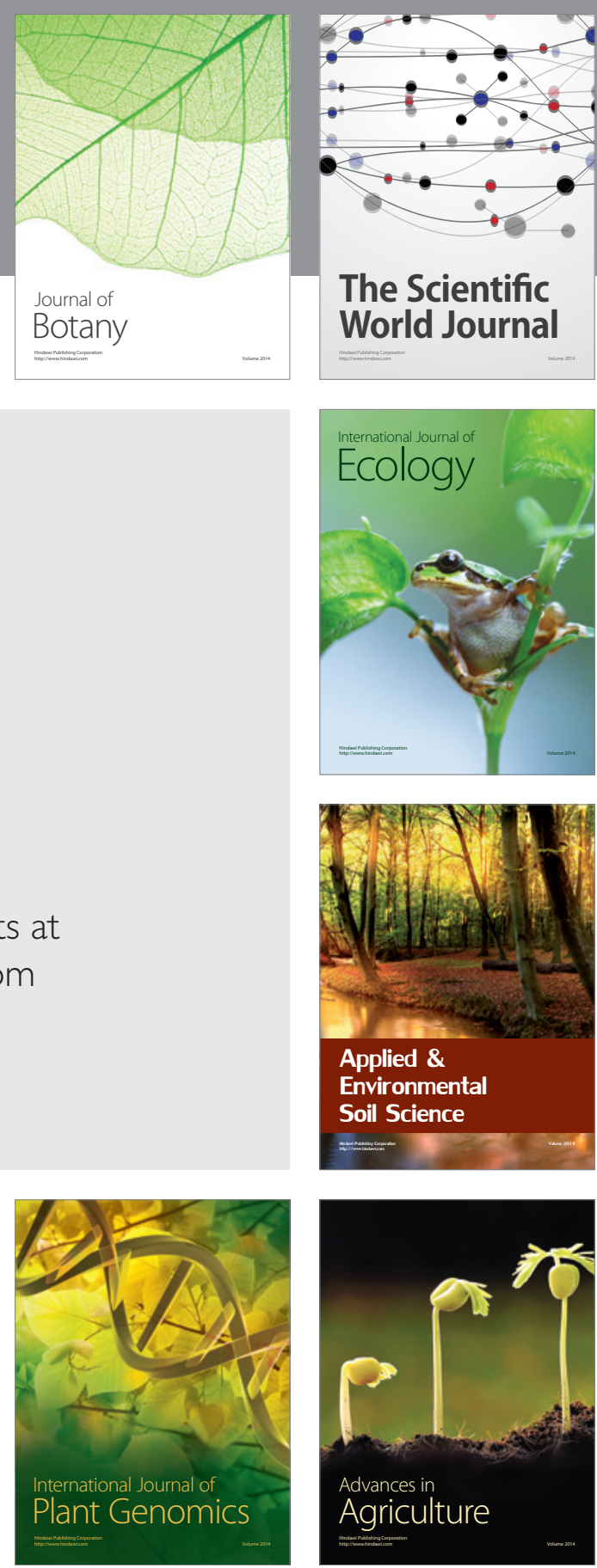

The Scientific World Journal
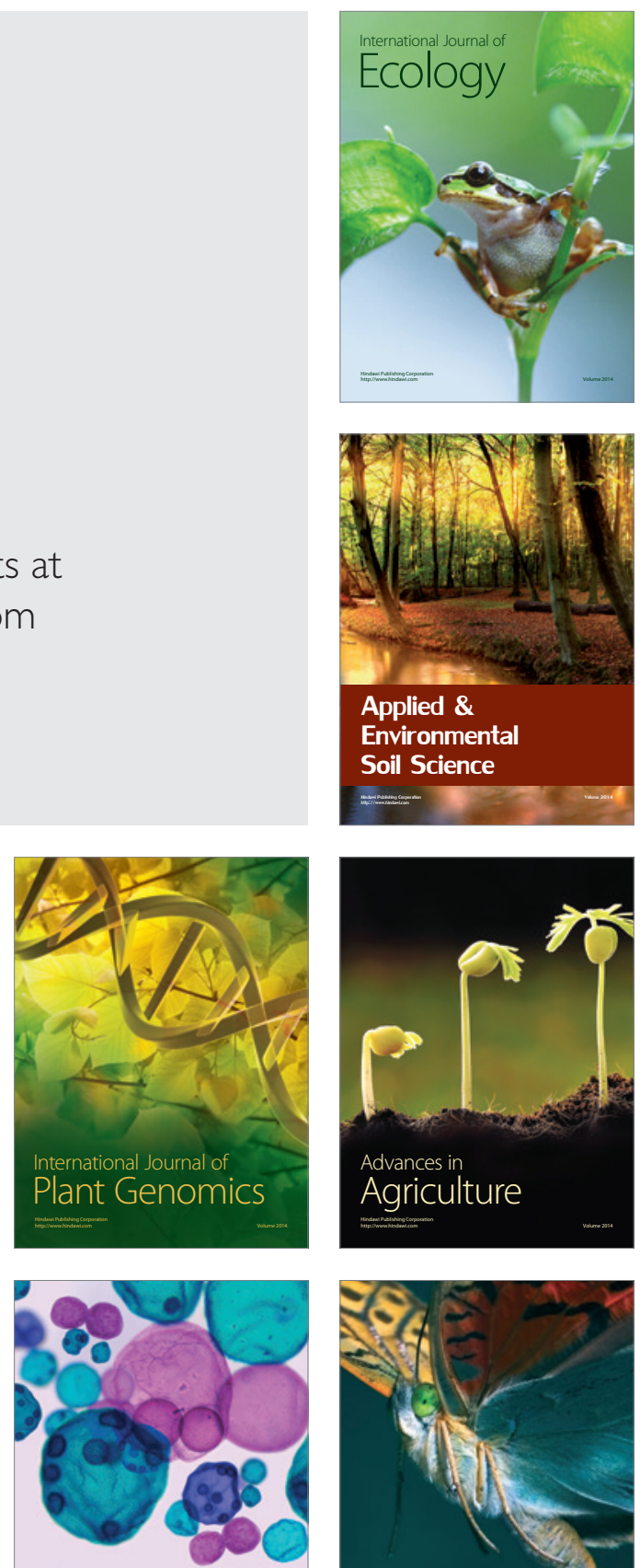

International Journal of Microbiology

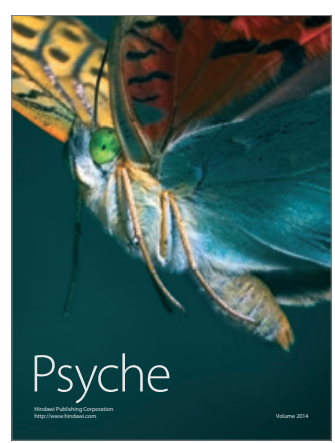

